NBER WORKING PAPER SERIES

\title{
THE RISE OF U.S. ANTIDUMPING ACTIONS IN HISTORICAL PERSPECTIVE
}

\author{
Douglas Irwin \\ Working Paper 10582 \\ http://www.nber.org/papers/w10582
NATIONAL BUREAU OF ECONOMIC RESEARCH 1050 Massachusetts Avenue
Cambridge, MA 02138
June 2004

This paper was prepared for a symposium marking the centennial of antidumping legislation, held at the University of Michigan on March 12, 2004. I thank Bruce Blonigen, Mike Finger, Thomas Prusa, Shang-Jin Wei, and seminar participants at Michigan, Dartmouth, and the International Monetary Fund for helpful comments and advice. This paper was revised while the author was a visiting scholar in the Trade Unit of the IMF's Research Department. The views expressed herein are those of the author(s) and not necessarily those of the National Bureau of Economic Research.

(C2004 by Douglas Irwin. All rights reserved. Short sections of text, not to exceed two paragraphs, may be quoted without explicit permission provided that full credit, including $(\mathbb{C}$ notice, is given to the source. 
The Rise of U.S. Antidumping Actions in Historical Perspective

Douglas Irwin

NBER Working Paper No. 10582

June 2004

JEL No. F1

\section{$\underline{\text { ABSTRACT }}$}

Empirical studies of antidumping activity focus almost exclusively on the period since 1980 . This paper puts recent U.S. antidumping experience in historical context by studying the determinants of annual case filings over the past half century. The conventional view that few antidumping cases existed prior to 1980 is not correct, although most did not result in the imposition of duties. The increased number of cases in recent decades largely reflects petitions that target multiple source countries; the number of imported products involved has actually fallen since the mid 1980s. The annual number of antidumping cases is influenced by the unemployment rate, the exchange rate, import penetration (closely related to the decline in average tariffs), and changes in the antidumping law and its enforcement in the early 1980s.

Douglas Irwin

Department of Economics

Dartmouth College

Hanover, NH 03755

and NBER

douglas.irwin@dartmouth.edu 


\section{Introduction}

Antidumping provisions have been a part of U.S. trade law for over eighty years, but have been prominent only in the past two decades. Antidumping was such an obscure part of U.S. trade policy that there was virtually no economic research on the topic until the pioneering paper of Finger, Hall and Nelson (1982). Since then, research on antidumping policy has focused almost exclusively on the period since $1980 .{ }^{1}$ As a result, we know very little about the use of antidumping laws prior to 1980 and the degree to which there has been a shift toward more intensive use of antidumping remedies over time.

The purpose of this paper is to put the recent U.S. antidumping experience in historical perspective, focusing in particular on the period since World War II. This perspective enables us to answer several questions. Is it true that few antidumping petitions were filed prior to 1980 ? If so, what explains that low level of antidumping activity, given that it is now considered to be an “easy" way for import-competing firms to gain protection? And what economic and political factors explain the shift toward a more intensive use of antidumping remedies over time? Only by looking at the historical experience with antidumping can we shed light on these questions.

An examination of the entire history of U.S. antidumping policy reveals the following:

- the number of antidumping investigations conducted in the late 1930s and the late 1950s and early 1960s is surprisingly large and comparable to the post-1980s levels of activity;

- most antidumping investigations prior to the 1970 s were dismissed by the Treasury

${ }^{1}$ See Blonigen and Prusa (2003) for an excellent survey of the economic literature on antidumping measures. 
Department as lacking evidence of less-than-fair-value (LTFV) sales; by contrast, now virtually all petitions move on to the injury determination stage of the process;

- the increase in antidumping cases since the early 1980s is related to the rise of multiple petitions, i.e., petitions that cite several source countries of dumping the same product in the U.S. market; in fact, the number of products targeted in antidumping cases has fallen since the mid1980s;

- the proximate determinants of the annual number of antidumping cases is the unemployment rate, the exchange rate, import penetration, and a 1984 legal change that encouraged the filing of multiple petitions.

This paper first examines some of the legal and administrative changes in antidumping policy since its inception. The paper then performs the simple service of collecting and presenting data on the annual number of antidumping investigations over time. Finally, a simple econometric model is used to examine the importance of various determinants of the annual number of antidumping investigations.

\section{The Evolution of U.S. Antidumping Law}

The precursors to U.S. antidumping legislation emerged in the late nineteenth century from the antitrust movement and concerns about the role of unfair competition in fostering the growth of monopolies. The Sherman Antitrust Act of 1890 declared illegal any effort to combine or conspire to monopolize a particular market. The Clayton Act of 1914 made price discrimination an illegal practice if it reduced competition or tended to create a monopoly.

Legislation enacted shortly thereafter extended these principles to international trade. 
The Wilson Tariff of 1894 made it unlawful for foreign producers to combine or conspire to monopolize the U.S. market. ${ }^{2}$ Similarly, the Antidumping Act of 1916 (part of the Revenue Act of 1916) made it illegal to sell imported goods at prices substantially lower than the market value in the exporting country "with the intent of destroying or injuring an industry in the United States, or of prevent the establishment of an industry in the United States, or of restraining or monopolizing any part of trade and commerce in such articles in the United States."3 This 1916 antidumping law is a criminal statute with criminal punishments. The remedy is not higher import duties but rather fines (triple damages) and possible imprisonment for those found guilty. The law is rarely invoked because the exporter must be shown to have had "predatory intent" with the aim of limiting or restraining competition and proving such intent is difficult for the plaintiff. The law is still on the books, but it was recently ruled as inconsistent with WTO obligations. ${ }^{4}$

U.S. antidumping law as we currently know it really began with the Antidumping Act of 1921, part of the Emergency Tariff Act of that year. According to this law, "Whenever the Secretary of the Treasury finds that an industry in the United States is likely to be injured, or is prevented from being established, by reason of the importation into the United States of foreign merchandise, and that merchandise of such class or kind is being sold or is likely to be sold in significance."

${ }^{2}$ Viner (1923, p. 241) judges this part of the Wilson tariff to be "without practical

${ }^{3}$ Quoted in Congressional Budget Office (1994), p. 20.

4 The EU and Japan challenged the 1916 law as inconsistent with GATT 1994 since it does not have a material injury test as required by the Uruguay Round's Antidumping Agreement. In 2000, the WTO Appellate Body affirmed a panel ruling against the United States on the matter. 
the United States or elsewhere at less than its fair value, he shall make such finding public. ... [I]f the purchase price or the exporter's sales price is less than the foreign market value (or, in the absence of such value, than the cost of production), there shall be levied, collected, and paid a special dumping duty in an amount equal to such difference."

The Antidumping Act of 1921 contains all the elements of what we now recognize as antidumping: that duties may be imposed if the exporter's sales price is less than the foreign market value, that foreign costs of production may be calculated if the foreign market value is not ascertainable, that the dumping must be related to injury suffered by the domestic industry, that higher import duties are the appropriate remedy, etc.

The 1921 law differs markedly from the 1916 legislation. The 1916 law focuses on the intent of the exporter, whereas the 1921 law hinges on a finding of price discrimination and injury. The 1916 law is enforced in legal proceedings in the court system, whereas the 1921 law is administrated by executive agencies. In the 1916 law, dumping is related to some vague notion of predatory pricing, but in the 1921 law dumping occurs simply if foreign firms charge lower prices on products sold in the United States than in their home market, regardless of whether predation is an issue. The remedy in the 1916 law is fines and possible imprisonment, whereas the remedy in the 1921 law is higher import duties (if injury to domestic producers is found).

Thus, the 1921 law set the stage for antidumping filings in a way that the 1916 law could

${ }^{5}$ Quoted in CBO (1994), p. 21. Thus, the United State was slow to follow the example of Canada, which enacted the first antidumping law in 1904. It is ironic that Canada developed antidumping laws to block steel imports from the United States (particularly from the U.S. Steel Corporation) and now, a century later, the U.S. steel industry is among the major users of the law to stop imports. 
not. As Finger (1993, p. 24) notes: "Under the softer standard of interpretation and proof, administration of the law could follow changing political pressures for protection much more quickly than a more rigorous, rule-of-law standard would allow. Thus it prepared the way for the eventual emergence of antidumping as the main vehicle for import-competing interests to press for protection - and for governments to respond to those pressures."

Despite this, antidumping was not a critical component of U.S. trade policy during the 1920s and 1930s, nor in the period immediately following World War II. U.S. import tariffs were quite high through the 1920s and early 1930s and import penetration (measured by the ratio of imports to GDP) was very low. Although tariffs began to fall by the mid 1930s, due in part to negotiations reached under the Reciprocal Trade Agreements Act of 1934, domestic producers could invoke various trade laws to obtain protection from foreign competition. ${ }^{6}$ But antidumping was not an easy avenue for obtaining import relief, as statistics discussed in the next section will indicate.

Yet policymakers did not forget about the antidumping law. The United States was the main proponent of including antidumping procedures in Article VI of the General Agreement on

6 The Tariff Commission helped enforce several different trade laws during this period. For example, Section 337 of Tariff Act of 1930 authorized the Tariff Commission to investigate alleged unfair methods of competition relating to imports when the effect or tendency of such methods or acts is to destroy or substantially injure a domestic industry, or to prevent the establishment of an industry, or to restrain or monopolize the trade and commerce of the United States. Section 336 of the Tariff Act of 1930 - the so-called flexible tariff provision - sets forth a procedure under which an import duty could be changed by proclamation of the president after an investigation and report by the Commission on the differences between the cost of production in the United State and in its principal foreign supplier. In addition, Section 22 of the Agricultural Adjustment Act of authorizes the president to restrict imports of a commodity that render ineffective or interfere materially with U.S. agricultural programs (notably price supports). 
Tariffs and Trade in 1947. Indeed, the 1921 legislation formed the textual basis for Article VI. But Congress has been sensitive to any weakening of U.S. antidumping policy in multilateral negotiations. For example, the Kennedy Round negotiations in the 1960s arrived at an antidumping code with a much more stringent definition of "material injury" than in U.S. law. Congress objected to the higher standard and passed a law stipulating that the United States would abide by the code only so long as it did not conflict with existing U.S. law.

In the 1970s and 1980s, as demand for antidumping measures increased, Congress passed legislation that changed various features of the antidumping law and made import duties a more likely outcome of the process. The Trade Act of 1974 expanded the definition of dumping to include home market sales below the average cost of production. The Trade Agreements Act of 1979 repealed the Antidumping Act of 1921 and the revised antidumping law was enacted as a new Title VII to the Tariff Act of 1930. This act shortened the time limits for antidumping investigations and determinations and allowed the use of "best information available" in cases where foreign firms did not provide information requested of them. The Trade and Tariff Act of 1984 required that the International Trade Commission cumulate the imports of all countries subject to an antidumping investigation when making an injury determination. This increased the benefit to domestic firms of filing petitions targeting several different countries of dumping the same product. ${ }^{7}$

In addition to these legal changes, Congress made two important administrative changes to the antidumping process in 1954 and 1979. (See Table 1.) Originally, the Treasury Department had full responsibility for determining if foreign merchandise had been imported at

${ }^{7}$ See Hansen and Prusa (1996). 
less than fair value (LTFV) and investigating whether the domestic industry was injured as a result of such imports. Effective October 1, 1954, Congress shifted the injury investigation from Treasury to the U.S. Tariff Commission (now the International Trade Commission). Since the Tariff Commission routinely conducted such investigations in enforcing other trade laws, this shift appears to have been motived mainly by issues of administrative expertise. Treasury Department officials supported this change, noting that injury determination was "completely outside the ordinary scope of departmental activities."8

Effective January 1, 1980, the Carter Administration shifted the LTFV determination to the Department of Commerce. With Congress's consent, this shift took place in part because of the perceived indifference of Treasury to the plight of petitioning firms. As a report of the House Ways and Means Committee noted in 1979, “This Committee has long been dissatisfied with the administration of the antidumping and countervailing duty statutes by the Treasury Department .... Given Treasury's performance over the past 10 years, many have questioned whether the dumping and countervail investigations and policy functions should remain in the Treasury Department."9 In its report, the House (1979, pp. 6-7) committee noted (without specifically naming the Treasury Department) that "past deficient administration of these laws" were due to "low priority and inadequate staffing levels." The committee noted that the shift "will give these functions high priority within a Department whose principle mission is trade. In the past agencies have arbitrarily set a course of administration of these statutes contrary to

8 Annual Report of the Secretary of the Treasury, FY 1953-54, p. 304.

9 Committee on Ways and Means, U.S. House of Representatives. Report on the Trade Agreements Act of 1979. House Report No. 317, 96 $6^{\text {th }}$ Congress, $1^{\text {st }}$ Session. July 1979, p. 24. 
congressional intent."

Thus, changes in the legal provisions of the antidumping law and in the administrative enforcement of the law were designed to facilitate the filing of petitions and increase the probability of import duties as being the final outcome.

\section{Antidumping Activity over Time}

As noted in the introduction, most economic research on U.S. antidumping policy has not examined the pre-1980 experience. The failure to study antidumping measures prior to 1980 is due to the lack of readily available data from that period and the perception that antidumping was not very important at that time. As a result, economists have little sense for the overall trend in U.S. antidumping activity prior to 1980 .

To shed some light on antidumping prior to 1980, Figure 1 presents the annual number of antidumping cases filed since 1922. (These data are presented and their sources described in the Appendix.) This figure reveals that antidumping cases were by no means nonexistent prior to 1980. Indeed, antidumping filings were quite pronounced during the late 1930s, even rivaling the large number of cases in the early 1980s and early 1990s. In addition, there was a steady and fairly substantial stream of cases from the mid 1950s until the mid 1960s.

Figure 2 focuses on the post-World War II period, where greater case detail is available.

10 The House report also noted (p. 8), "One of the major criticism of moving international trade functions to the Commerce Department has been the orientation of that Department toward its domestic business constituency. This perception may be true at this time; if so, it is an orientation which the Department must change. Too great protection of domestic markets will effectively smother U.S. export potential, as other governments retaliate with their own protectionist barriers against U.S. imports." 
This figure presents the total number of cases and the number of cases relating to a particular imported product. Each antidumping petition targets imports from a single country source. Prior to the early $1980 \mathrm{~s}$, most domestic industries filed a single petition that targeted imports of a particular product from a particular country. Since then, the number of multiple petitions has increased significantly. For example, of the 65 cases filed in FY 1991, six petitions concerned carbon steel standard pipe, seven dealt with wire rope, nine related to coated ground wood paper, fourteen addressed ball bearings, and so on. Though there were 65 individual investigations in this year, only 26 different imported commodities were the subject of scrutiny. Indeed, the surges in antidumping activity in 1992-94 and 1998-2001 are directly related to the multiple petitions filed by the steel industry.

The increase in multiple petitions reflect several factors. First, the number of countries that supply the United States with a particular product has increased over the post-war period. To prevent the trade diversion that would occur if only one source of imports was affected by antidumping duties, domestic petitioners have a growing incentive to file multiple petitions. In addition, as noted earlier, a legal change in 1984 requires the International Trade Commission to cumulate imports from all petitions in making injury determinations. This gives petitioning firms an extra incentive to file multiple petitions to raise the probability of an affirmative injury finding.

As Figure 2 illustrates, after adjusting the total number of antidumping petitions for those covering the same product, the number of products targeted by antidumping filings after 1980 does not appear to be significantly higher than in previous decades. When looked at from the perspective of the number of products targeted, antidumping seems to have peaked around 1985 
and to have declined since then. The message of Figure 2 is therefore strikingly contrary to the conventional view - antidumping may not be more important after 1980 than before.

Of course, each antidumping action now may have a greater negative impact on trade than in the past. As Blonigen (2003) notes, antidumping margins have risen significantly since the 1980s, so that the impact of antidumping duties on trade is greater. Furthermore, the rise of multiple petitions means that imports are more broadly shut out of the market when duties are imposed. While single petitions gave rise to substantial trade diversion, as countries not facing the antidumping duties increased their exports significantly after the imposition of duties, such diversion is less likely when multiple petitions are the norm.

Figure 3 plots the total number of cases and the number of cases in which an injury determination (either affirmative or negative) was made. An injury determination is required before antidumping duties can be imposed. As the figure illustrates, although many antidumping cases were filed in the late 1950s and early 1960s, very few cases reached the injury determination stage. Of those that did, injury was not often found to exist. Table 2 documents this point by presenting the disposition of antidumping cases between 1934 and 1954. During that period, only 5 percent of all cases resulted in import duties. In more than 80 percent of all cases, a finding of no dumping was made, either because imports were not found to be priced at LTFV, dumping margins were minimal, or petitions were withdrawn. As a result, no injury ruling by the Treasury was required. Only a quarter of the remaining cases (five percent of all cases) was there an affirmative injury finding.

The dearth of injury rulings began to change in the early 1970s and, by the mid-1980s, virtually every case filed received an injury determination one way or the other. Figure 4 
illustrates this development and shows that, since the late 1970s, roughly half of all ITC injury determinations are affirmative.

In conclusion, the number of antidumping investigations is clearly greater after 1980 than before, largely because of the increased propensity of firms to file multiple petitions. The number of imported products targeted for antidumping action has been remarkably stable over time. In addition, since the late 1970 s, almost every case reaches the injury determination stage.

\section{Determinants of Antidumping Cases Filed}

None of the existing studies of the determinants of aggregate U.S. antidumping activity notably Feinberg (1989), Leidy (1997), and Knetter and Prusa (2003) - examine the pre-1980 period. Therefore, the data described above can be used to explore some of the economic and political factors accounting for the rise in antidumping actions since the end of World War II.

Knetter and Prusa (2003) focus on two primary determinants of the annual number of antidumping cases - the change in real GDP and the real exchange rate. They find that an appreciation of the real exchange rate (with a one year lag) leads to an increase in the number of antidumping petitions filed. Although a decline in real GDP leads to an increase in filings, the change in real GDP (with a three year lag) is not a statistically significant determinant of antidumping filings when steel cases are excluded.

Exchange rates and business cycles might also explain the lower level of antidumping activity during the 1950s and 1960s. During that period, the Bretton Woods system of fixed exchange rates ensured that real exchange rate movements were minimal. In addition, business cycle fluctuations were relatively mild. Starting in the early 1970s, exchange rate variability 
increased and the U.S. economy experienced some severe business cycle downturns. The rise in the use of antidumping remedies coincides with these economic changes.

From a longer term perspective, at least two other factors could also account for the rise in antidumping activity over the postwar period - the increased role of import competition in the U.S. economy, and legal and administrative changes in antidumping policy.

First, the exposure of American industries to import competition clearly increased over the post-war period. Figure 5 shows that the ratio of merchandise imports to GDP starts to rise in the late 1960s. The import/GDP ratio increased from about 3 percent of GDP in the 1950s and 1960 s to about 8 percent in the 1980 s and reached more than 10 percent by the end of the 1990 s. This rise in import penetration is plausibly related to the decline in the average tariff on dutiable imports. The average tariff fell quite sharply in the late 1960s and early 1970s due to the reduction in tariff rates as a result of the Kennedy Round of multilateral trade negotiations and the impact of higher import prices on the ad valorem equivalent of the many specific duties in the tariff code. ${ }^{11}$ The timing of the decline in tariffs on dutiable imports and the rise in import penetration is quite striking. The correlation between these two series is -0.94 . This decline in trade barriers exposed many industries to foreign competition and may have pushed them toward using antidumping duties to protect themselves.

A second factor that could account for the rise in antidumping activity is institutional changes in the administration of the antidumping law. As reported earlier, various subtle changes in the legal requirements for antidumping relief in 1974, 1980, and 1984, may have

11 Irwin (1998) examines how the combined impact of changing tariff rates and fluctuations in import prices has affected the average U.S. tariff over time. 
increased the number of antidumping complaints by raising the probability of obtaining import relief. In addition, in 1980 the Commerce Department replaced the Treasury Department as the institution responsible for LTFV determinations. The shift took place because Treasury was perceived to be relatively indifferent to antidumping petitions, whereas Commerce was expected to be a more sympathetic advocate for domestic firms seeking protection. Simply changing the agency responsible for handling the complaints may have constituted a regime shift that increased the number of petitions.

The relative importance of these potential determinants of antidumping activity can be sorted out by regressing the annual number of antidumping cases on various independent variables. Following the work of Knetter and Prusa (2003), two macroeconomic determinants of antidumping filings are the change in the log of real GDP and the log of the foreign exchange value of the dollar. The first measures the rate of U.S. economic growth; previous studies have found that the number of antidumping petitions increases during a recession and decrease during an expansion, although the relationship has been found to be weak. ${ }^{12}$ The unemployment rate is an alternative variable that will be used as well.

The exchange rate used here is the nominal effective U.S. dollar exchange rate from the IMF's International Financial Statistics. The real exchange rate has been used in other studies, but it is available from the IMF and other authorities only since 1975. As is well known, however, movements in nominal exchange rates are closely related to movements in real exchange rates; indeed, for the period 1975 to 2002 the correlation between the nominal and real

12 The data are from the website of the Commerce Department's Bureau of Economic Analysis (www.bea.gov). 
effective exchange rate of the dollar is 0.90 .

In addition, the regressions will use measures of import competition - the merchandise import to GDP ratio and the average tariff - and a dummy variable to capture administrative changes. ${ }^{13}$ Both are exogenous variables from the standpoint of any individual industry that is considering appealing to the government for protection. Finally, dummy variables taking the value of one for the periods after 1974, 1979, and 1984 will represent the effects of legal and administrative changes on the number of filings. Strictly speaking, the dummy variables capture any omitted factors after these years that would increase antidumping filings, but the variables are plausibly linked to legal and administrative changes at that time.

Table 3 presents some econometric results ion which the dependent variable is simply the number of cases filed in any given fiscal year. Since the dependent variable is a count measure, the models are estimated by a negative binomial regression. ${ }^{14}$ From column (1), using the main variables employed by Knetter and Prusa (2003), it appears that changes in GDP and the exchange rate are not systematically related to the annual number of filings over the longer timeperiod considered here. However, as column (2) shows, the unemployment rate, rather than the change in real GDP, appears to be more precisely related to the number of antidumping petitions. A higher unemployment rate is related to more antidumping cases.

Column (3) shows that the results improve when import penetration (measured by the

13 The import/GDP data is from the BEA. The average tariff figures are from the Department of Commerce's Historical Statistics of the United States, updated by the U.S. International Trade Commission.

14 See Cameron and Trivedi (1998). A more sophisticated approach would take into account the possibility of serial correlation in the regression. 
import to GDP ratio) is included with the macroeconomic determinants. Not surprisingly, a rise in import penetration increases the number of antidumping filings. The coefficient on the exchange rate reverses its sign from the previous column and becomes statistically significant. As expected, an appreciation in the foreign exchange value of the dollar leads to more antidumping filings. Column (4) shows that the results do not change substantially with the substitution of the average tariff on dutiable imports for import penetration, although the coefficient on unemployment is estimated less precisely.

Column (5) includes three dummy variables for the years starting in 1975, 1980, and 1985, to represent the impact of the 1974 and 1984 legal changes and the 1980 shift of antidumping responsibilities to the Commerce Department. These dummy variables reduce the impact of import penetration, but do not change the effect of unemployment or the exchange rate on antidumping cases. However, the only dummy variable that is positive and statistically significant is that for the 1984 legal change which gave firms the incentive to file multiple petitions. Taking the exponential of the coefficient on the dummy variable indicates that the conditional mean of the number of cases is 2.12 times higher after 1984 . This implies a substantial effect: a 112 percent increase translates into an additional 22 cases per year from pre 1984 levels.

To facilitate a comparison of the importance of each of these factors, the next column reports coefficients on the standardized variables. The effects of the unemployment rate, the exchange rate, and import penetration are roughly comparable: a one standard deviation increase in the exchange rate leads to about a 0.23 standard deviation increase in the number of filings. Thus, there is a rough symmetry between comparably sized changes in these variables in terms 
of their impact on the number of antidumping cases.

Table 4 considers two different dependent variables, the annual number of products covered in antidumping cases (i.e., multiple petitions concerning a single product become one observation) and the number of injury determinations (both affirmative and negative). As in the previous table, the unemployment rate, the exchange rate, the import penetration ratio, and the 1984 legal change all appear to be important determinants of the number of products which are involved in antidumping cases (column 1). In explaining the declining number of products targeted after the mid-1980s, the impact of the drop in the unemployment rate and the lower foreign exchange value of the dollar must have dominated the continued rise in import penetration and the 1984 legal change.

The results in column (2) indicate that the same factors are at work in explaining the number of cases that receive an injury determination. ${ }^{15}$ In this case, the coefficient on the 1984 legal change is more than double that in the previous column. This indicates that the cumulation requirement appears to have had an impact on the number of cases getting to the injury stage.

Several conclusions cut across these findings. Changes in real GDP do not appear to be systematically related to antidumping activity. This suggests that the industry-specific cycles that trigger antidumping demands are not necessarily correlated with the economy-wide business cycle. (The difficulties faced by the steel industry after the Asian financial crisis in 1997, for example, coincided with robust economic growth in the United States.) Rather, the two macroeconomic phenomena that drive antidumping activity are the unemployment rate

15 Hansen and Prusa (1997) investigate the political and economic factors behind whether the ITC renders an affirmative or a negative injury finding. 
(positively related) and the exchange rate (appreciations being positively related). In addition, the increasing role of imports in the economy - related to the decline in average levels of protection - is also positively related to the number of antidumping filings. ${ }^{16}$

Finally, as the dummy variable indicates, something clearly happened to the level of antidumping activity after 1984. In that year, the Congress changed the antidumping law to require the ITC to cumulate the impact of all imports from countries against whom a petition had been filed in rendering its injury decision. This gave import-competing firms an incentive to file more antidumping petitions against other countries for a given product. The effect could also represent the lagged impact of a major institutional change - the shift in administrative responsibility from Treasury to Commerce. The Commerce Department was much more apt to find LTFV sales, leading to many more petitions filed and injury determinations made. Thus, empirical results that focus exclusively on the period after 1979 may fail to capture the importance of legal changes and bureaucratic incentives in giving rise to additional antidumping activity.

\section{Conclusion}

This paper has put recent U.S. antidumping experience in historical perspective by studying the number of AD cases prior to the 1980s. Contrary to the conventional view, many antidumping petitions had been filed in previous decades, particularly in the late 1950s and early

16 This substitution is to be expected and perhaps even welcomed. Fischer and Prusa (2003) argue that contingent protection dominates high average protection as a mechanism for insuring import-competing firms and their workers from import shocks. So from a welfare perspective, sector-specific contingent protection measures are superior to uniform noncontingent tariffs. 
1960s and again in the early 1970s. Unlike today, however, most of these petitions did not result in the imposition of antidumping duties. The greater number of petitions in recent years reflects the tendency of firms to file multiple petitions, while the number of products targeted for antidumping measures has actually declined since the early 1980s.

In terms of the empirical results, the annual number of antidumping investigations is affected by two macroeconomic factors - unemployment and the exchange rate. In addition, the trend toward greater import penetration in the U.S. economy dating from the early 1970s (a factor that is highly correlated with declining average tariffs) and legal and administrative change in antidumping policy have also had an impact on the number of antidumping cases. 


\section{References}

Baldwin, Robert E. "Imposing Multilateral Disciple on Administered Protection." In Anne O. Krueger (ed.), The WTO as an International Organization. Chicago: University of Chicago Press, 1998.

Blonigen, Bruce. "Evolving Discretionary Practices of U.S. Antidumping Activity." NBER Working Paper No. 9625, April 2003.

Blonigen, Bruce, and Thomas J. Prusa. "Antidumping." In E. Kwan Choi and James Harrigan (eds.), Handbook of International Trade. Oxford: Blackwell, 2003.

Cameron, A. Colin, and Pravin K. Trivedi. Regression Analysis of Count Data. New York: Cambridge University Press, 1998.

Congressional Budget Office. How the GATT Affects U.S. Antidumping and Countervailing Duty Policy. Washington, D.C., September 1994.

Feinberg, Robert M. "Exchange Rates and Unfair Trade." Review of Economics and Statistics 71 (November 1989): 704-707.

Fischer, Ronald D., and Thomas Prusa. "WTO Exceptions as Insurance.” Review of International Economics 11 (November 2003): 745-757.

Finger, J. Michael. "The Origins and Evolution of Antidumping Regulation." In J. M. Finger (ed.), Antidumping: How It Works and Who Gets Hurt. Ann Arbor: University of Michigan Press, 1993.

Finger, J. Michael, H. Keith Hall, and Douglas R. Nelson. "The Political Economy of Administered Protection." American Economic Review 72 (June 1982): 452-466.

Hansen, Wendy L., and Thomas J. Prusa. "Cumulation and ITC Decision-Making: The Sum of the Parts is Greater than the Whole.” Economic Inquiry 34 (October 1996): 746-69.

Hansen, Wendy L, and Thomas J. Prusa. "The Economics and Politics of Trade Policy: An Empirical Analysis of ITC Decision Making." Review of International Economics 5 (May 1997): 230-45.

Irwin, Douglas A. "Changes in U.S. Tariffs: The Role of Import Prices and Commercial Policies," American Economic Review 88 (September 1998): 1015-1026.

Knetter, Michael M., and Thomas J. Prusa, "Macroeconomic Factors and Antidumping Filings: Evidence from Four Countries." Journal of International Economics 61 (October 2003): 1-18. 
Leidy, Michael. "Macroeconomic Conditions and Pressures for Protection under Antidumping and Countervailing Duty Laws: Empirical Evidence from the United States." International Monetary Fund Staff Papers 44 (March 1997): 132-144.

U.S. House of Representatives, Committee on Ways and Means. Hearings on Amendments to the Antidumping Act of 1921, as Amended. $85^{\text {th }}$ Congress, $1^{\text {st }}$ Session. Washington, D.C.: GPO, 1957.

U.S. House of Representatives. Reorganization Plan No. 3 of 1979. House Report No. 96-585. $96^{\text {th }}$ Congress, $1^{\text {st }}$ Session. Washington, D.C.: GPO, 1979.

Viner, Jacob. Dumping: A Problem in International Trade. Chicago: University of Chicago Press, 1923. 
Appendix:

Annual Number of Antidumping Cases, Products, and Injury Determinations, by fiscal year.

\begin{tabular}{ccccc} 
& AD Filings & Products & Affirmative & Negative \\
\cline { 2 - 3 } 1947 & 1 & 1 & 0 & 0 \\
1948 & 3 & 2 & 0 & 0 \\
1949 & 13 & 10 & 0 & 5 \\
1950 & 15 & 14 & 0 & 3 \\
1951 & 6 & 5 & 0 & 0 \\
1952 & 5 & 5 & 0 & 1 \\
1953 & 9 & 6 & 0 & 8 \\
1954 & 14 & 3 & 0 & 4 \\
1955 & 15 & 12 & 1 & 5 \\
1956 & 18 & 10 & 0 & 1 \\
1957 & 41 & 28 & 0 & 2 \\
1958 & 13 & 7 & 0 & 2 \\
1959 & 45 & 35 & 0 & 2 \\
1960 & 33 & 15 & 1 & 3 \\
1961 & 32 & 20 & 3 & 4 \\
1962 & 16 & 8 & 0 & 2 \\
1963 & 42 & 29 & 1 & 5 \\
1964 & 27 & 17 & 3 & 8 \\
1965 & 22 & 20 & 1 & 2 \\
1966 & 16 & 13 & 1 & 2 \\
1967 & 9 & 4 & 2 & 0 \\
1968 & 13 & 10 & 4 & 1 \\
1969 & 21 & 18 & 7 & 2 \\
1970 & 23 & 9 & 15 & 1 \\
1971 & 22 & 21 & 7 & 7 \\
1972 & 39 & 34 & 10 & 13 \\
1973 & 27 & 25 & 9 & 10 \\
1974 & 10 & 10 & 2 & 4 \\
1975 & 14 & 10 & 2 & 4 \\
1976 & 22 & 18 & 1 & 9 \\
1977 & 19 & 3 & 9 & 6 \\
1978 & 47 & 37 & 7 & 8 \\
1979 & 41 & 28 & 11 & 7 \\
1980 & 16 & 20 & 9 & 15 \\
1981 & 14 & 13 & 4 & 5 \\
1982 & 35 & 27 & 12 & 25 \\
1983 & 46 & 20 & 12 & 14 \\
1984 & 38 & 36 & 16 & 13 \\
1985 & 69 & 42 & 26 & 20 \\
1986 & 83 & 23 & 37 & 14 \\
1987 & 16 & 20 & 17 & 15 \\
& & & &
\end{tabular}




$\begin{array}{ccccc}1988 & 42 & 15 & 21 & 14 \\ 1989 & 24 & 17 & 17 & 9 \\ 1990 & 35 & 13 & 15 & 4 \\ 1991 & 66 & 26 & 19 & 40 \\ 1992 & 84 & 25 & 38 & 47 \\ 1993 & 37 & 16 & 11 & 9 \\ 1994 & 51 & 22 & 29 & 26 \\ 1995 & 14 & 12 & 9 & 6 \\ 1996 & 21 & 11 & 9 & 2 \\ 1997 & 15 & 8 & 14 & 7 \\ 1998 & 36 & 9 & 22 & 11 \\ 1999 & 46 & 16 & 20 & 24 \\ 2000 & 45 & 12 & 18 & 15 \\ 2001 & 77 & 24 & 40 & 43 \\ 2002 & 35 & 14 & 12 & 21\end{array}$

Note on Sources: There is no consolidated and reliable source for early antidumping cases. Several sources were used in the construction of this time series. For the period 1922 to 1953, the source is http://ia.ita.doc.gov/stats/pre80ad.txt. This source is poorly documented. A more reliable and complete compilation of all cases prior to 1953 might be available by going through the Treasury's publication Treasury Decisions. For the period from 1953 to 1979 (fiscal years), the number of cases filed is reported in the Annual Report of the Secretary of the Treasury. After these data were compiled, I discovered that Baldwin (1998, p. 302) presents the same data for essentially the same period. For fiscal years 1980 to 2002, the source is an internal document from the Office of Investigations, International Trade Commission. 
Table 1: Administrative Responsibilities in Antidumping Policy

\begin{tabular}{lll}
\hline & Dumping Determination & \multicolumn{1}{c}{ Injury Determination } \\
\hline $1921-1954$ & Treasury Department & Treasury Department \\
$1954-1979$ & Treasury Department & Tariff Commission \\
$1979-$ present & Commerce Department & International Trade Commission \\
\hline
\end{tabular}

Note: The Tariff Commission was re-named the International Trade Commission in 1974.

Table 2: Outcomes of Antidumping Cases, 1934-1954

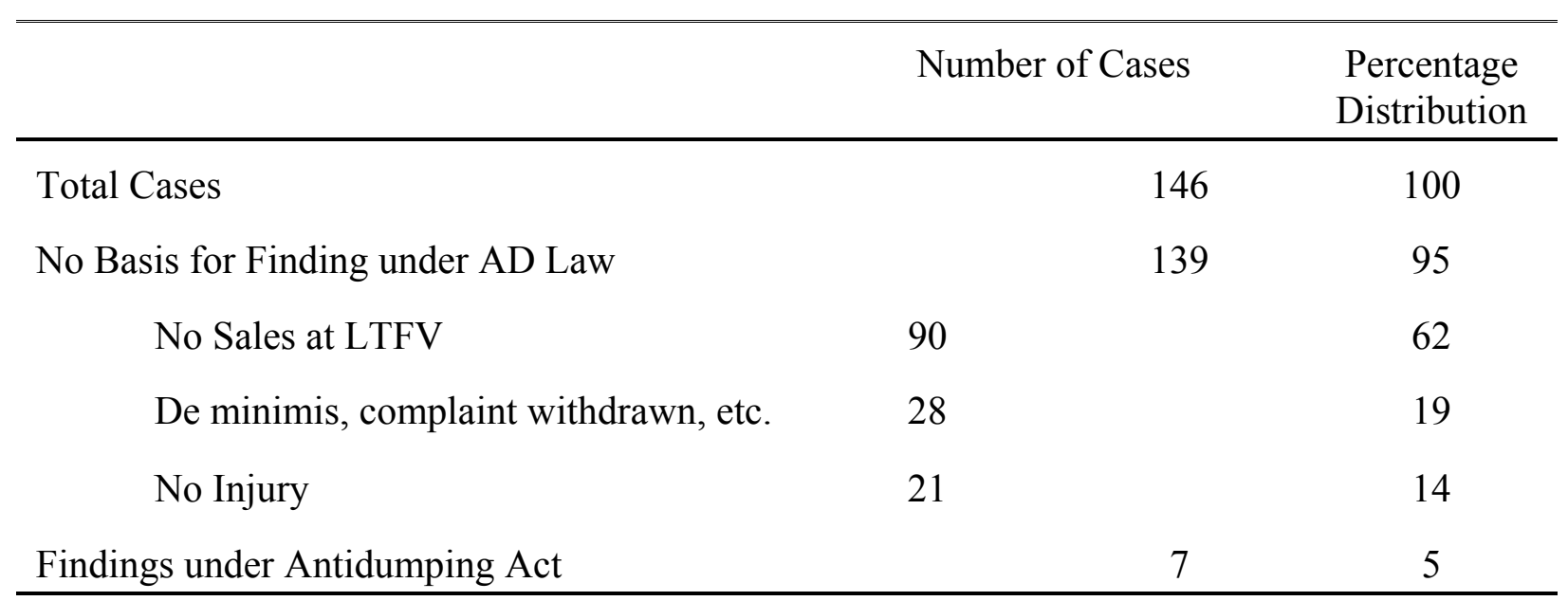

Source: Committee on Ways and Means, U.S. House of Representatives (1957), p. 15. 
Table 3: Determinants of Antidumping Cases, FY 1947-2002

Dependent Variable: Annual Number of Antidumping Cases

\begin{tabular}{|c|c|c|c|c|c|c|}
\hline & (1) & (2) & (3) & (4) & $(5)$ & $\begin{array}{l}\text { Standardized } \\
\text { Coefficients }\end{array}$ \\
\hline ) Log of GDP (-1) & $\begin{array}{l}-0.43 \\
(4.47)\end{array}$ & -- & -- & -- & -- & -- \\
\hline Unemployment Rate & -- & $\begin{array}{l}0.21 * \\
(0.06)\end{array}$ & $\begin{array}{l}0.13^{*} \\
(0.06)\end{array}$ & $\begin{array}{c}0.08 \\
(0.06)\end{array}$ & $\begin{array}{l}0.20 * \\
(0.08)\end{array}$ & $\begin{array}{l}0.25^{*} \\
(0.08)\end{array}$ \\
\hline $\begin{array}{l}\text { Log of Nominal Effective Exchange Rate } \\
(-1)\end{array}$ & $\begin{array}{l}-0.60 \\
(0.69)\end{array}$ & $\begin{array}{l}-0.60 \\
(0.59)\end{array}$ & $\begin{array}{l}1.62 * \\
(0.71)\end{array}$ & $\begin{array}{l}1.72 * \\
(0.72)\end{array}$ & $\begin{array}{l}1.77 * \\
(0.73)\end{array}$ & $\begin{array}{l}0.23^{*} \\
(0.09)\end{array}$ \\
\hline Log of Import/GDP Ratio & -- & -- & $\begin{array}{l}0.81 * \\
(0.18)\end{array}$ & -- & $\begin{array}{c}0.66 \\
(0.55)\end{array}$ & $\begin{array}{c}0.22 \\
(0.14)\end{array}$ \\
\hline Log of Average Tariff (Dutiable Imports) & -- & -- & -- & $\begin{array}{l}-1.24^{*} \\
(0.27)\end{array}$ & -- & -- \\
\hline Dummy Variable (starting 1975) & -- & -- & -- & -- & $\begin{array}{l}-0.30 \\
(0.62)\end{array}$ & -- \\
\hline Dummy Variable (starting 1980) & -- & -- & -- & -- & $\begin{array}{l}-0.20 \\
(0.39)\end{array}$ & -- \\
\hline Dummy Variable (starting 1985) & -- & -- & -- & -- & $\begin{array}{l}0.75^{*} \\
(0.28)\end{array}$ & $\begin{array}{l}0.61 * \\
(0.22)\end{array}$ \\
\hline Pseudo $\mathrm{R}^{2}$ & 0.52 & 0.55 & 0.56 & 0.56 & 0.57 & 0.57 \\
\hline Log Likelihood & -235.0 & -234.4 & -226.3 & -225.4 & -222.8 & -223.1 \\
\hline
\end{tabular}

Note: Estimated by a negative binomial regression. Robust standard errors are reported. * indicates statistical significance at the 10 percent level. 
Table 4: Determinants of Number of Products and Injury Determinations, FY 1947 - 2002

\begin{tabular}{lcc}
\hline \hline & $\begin{array}{c}(1) \\
\text { Number of Products }\end{array}$ & $\begin{array}{c}(2) \\
\text { Number of Injury } \\
\text { Determinations }\end{array}$ \\
\hline Unemployment Rate & $0.20^{*}$ & $0.23^{*}$ \\
Log of Nominal Effective Exchange & $(0.07)$ & $1.10)$ \\
Rate (-1) & $1.83^{*}$ & $(0.84)$ \\
Log of Import to GDP Ratio & $(0.57)$ & $2.22^{*}$ \\
Dummy Variable (starting 1975) & $0.85^{*}$ & $(0.64)$ \\
Dummy Variable (starting 1980) & $(0.49)$ & -1.21 \\
& -0.49 & $(0.74)$ \\
Dummy Variable (starting 1984) & $(0.58)$ & -0.01 \\
& -0.39 & $(0.34)$ \\
Pseudo R & $(0.38)$ & $0.83^{*}$ \\
Log Likelihood & $0.40^{*}$ & $(0.32)$ \\
\hline \hline
\end{tabular}

Note: Estimated by a negative binomial regression. Robust standard errors are reported. * indicates statistical significance at the 10 percent level. 
Figure 1: Annual Number of Antidumping Cases, FY 1922-2002

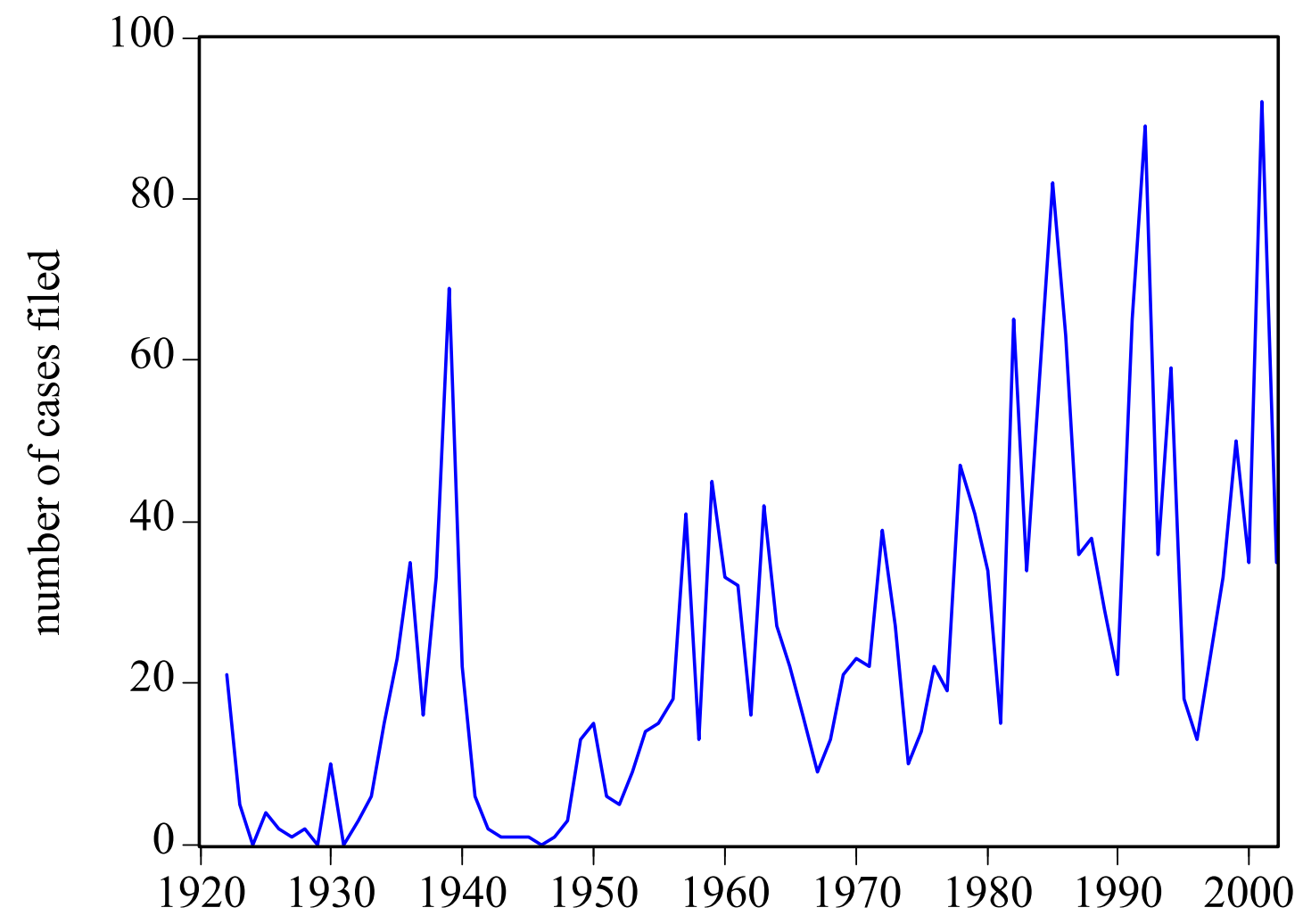

Source: See the appendix. 
Figure 2: Antidumping Cases, FY 1947-2002

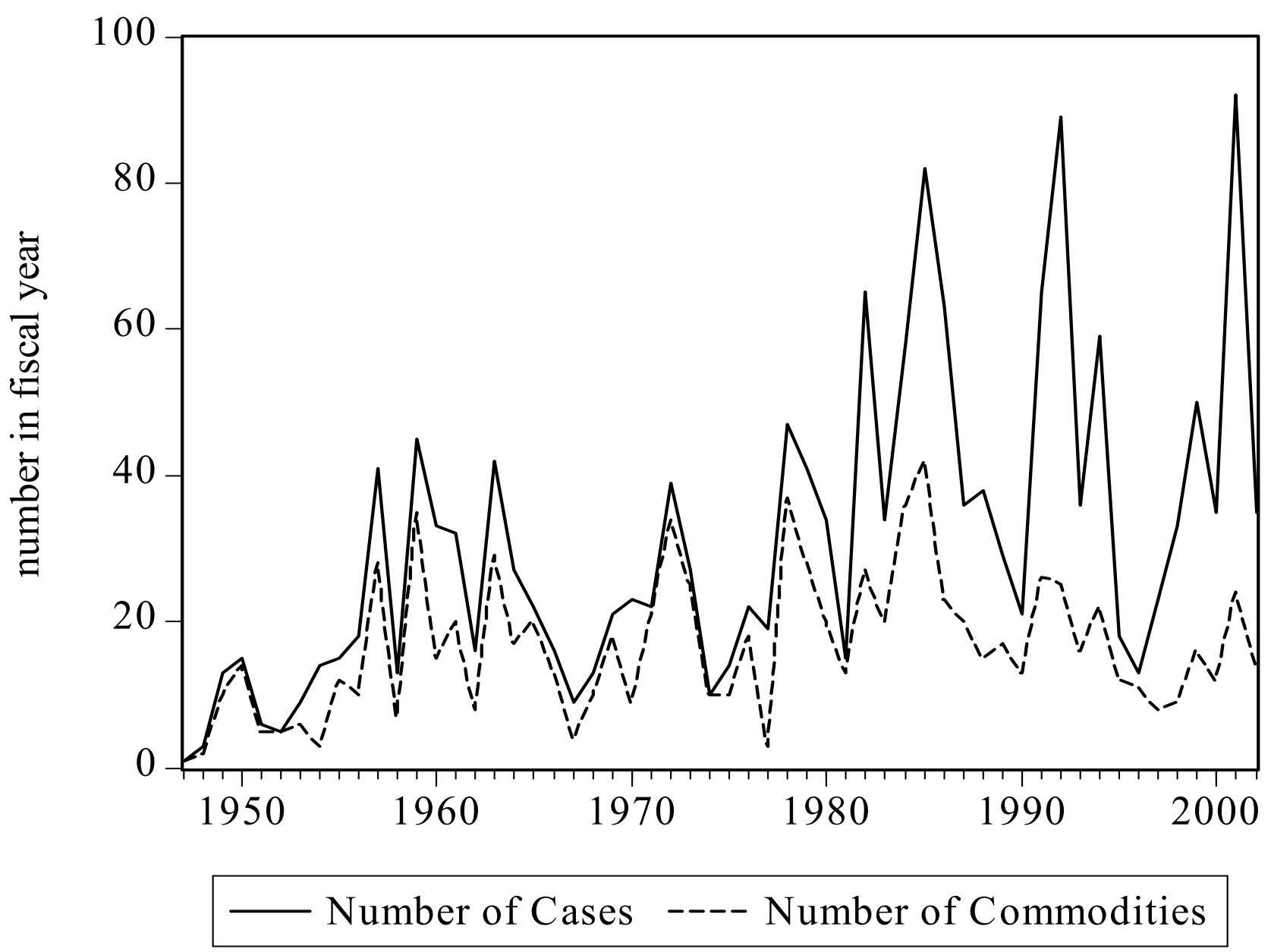

Source: See the appendix. 
Figure 3: Number of Antidumping Cases and Injury Determinations, FY 1947 - 2002

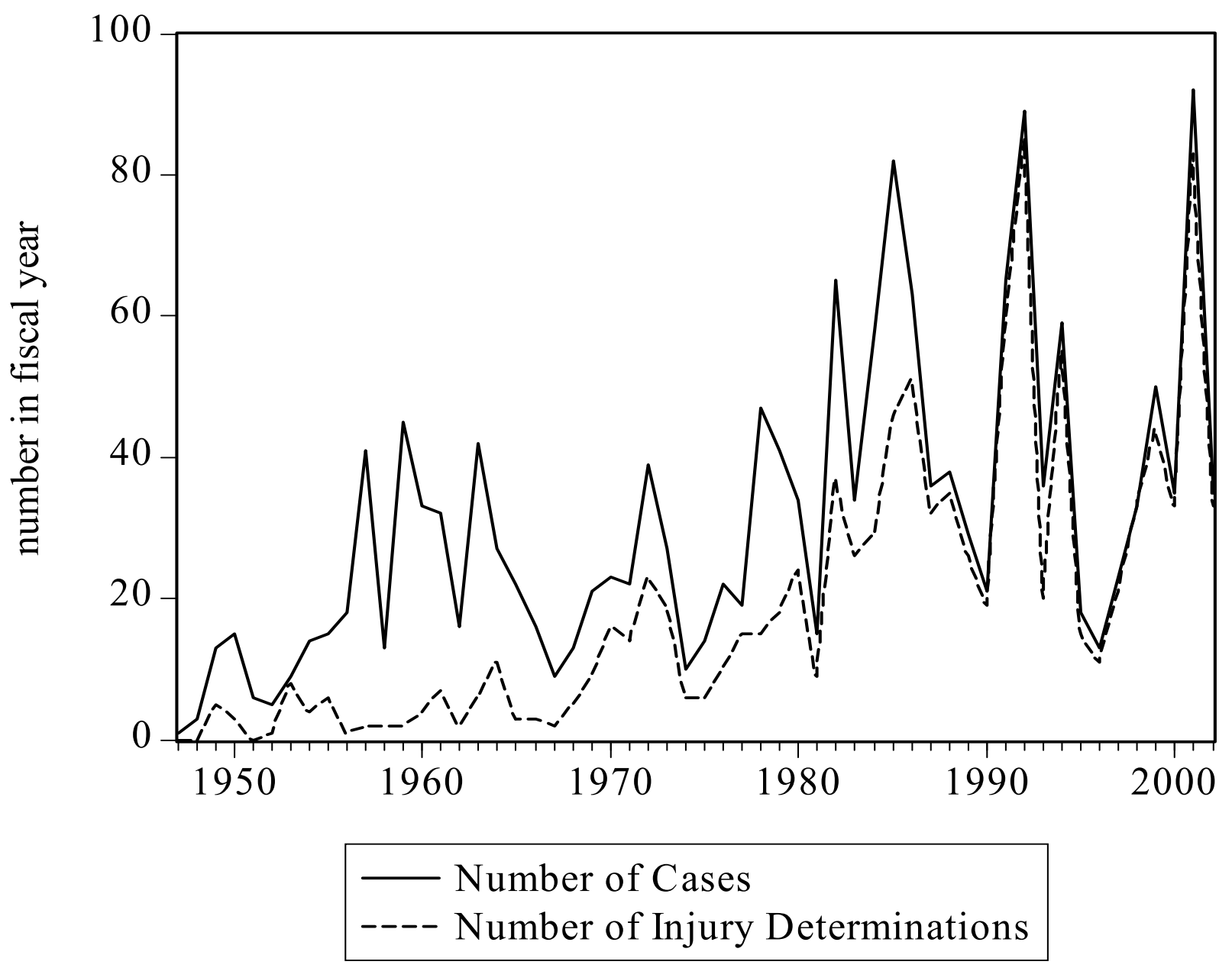

Source: See the appendix. 
Figure 4: Antidumping Injury Determinations, FY 1947-2002

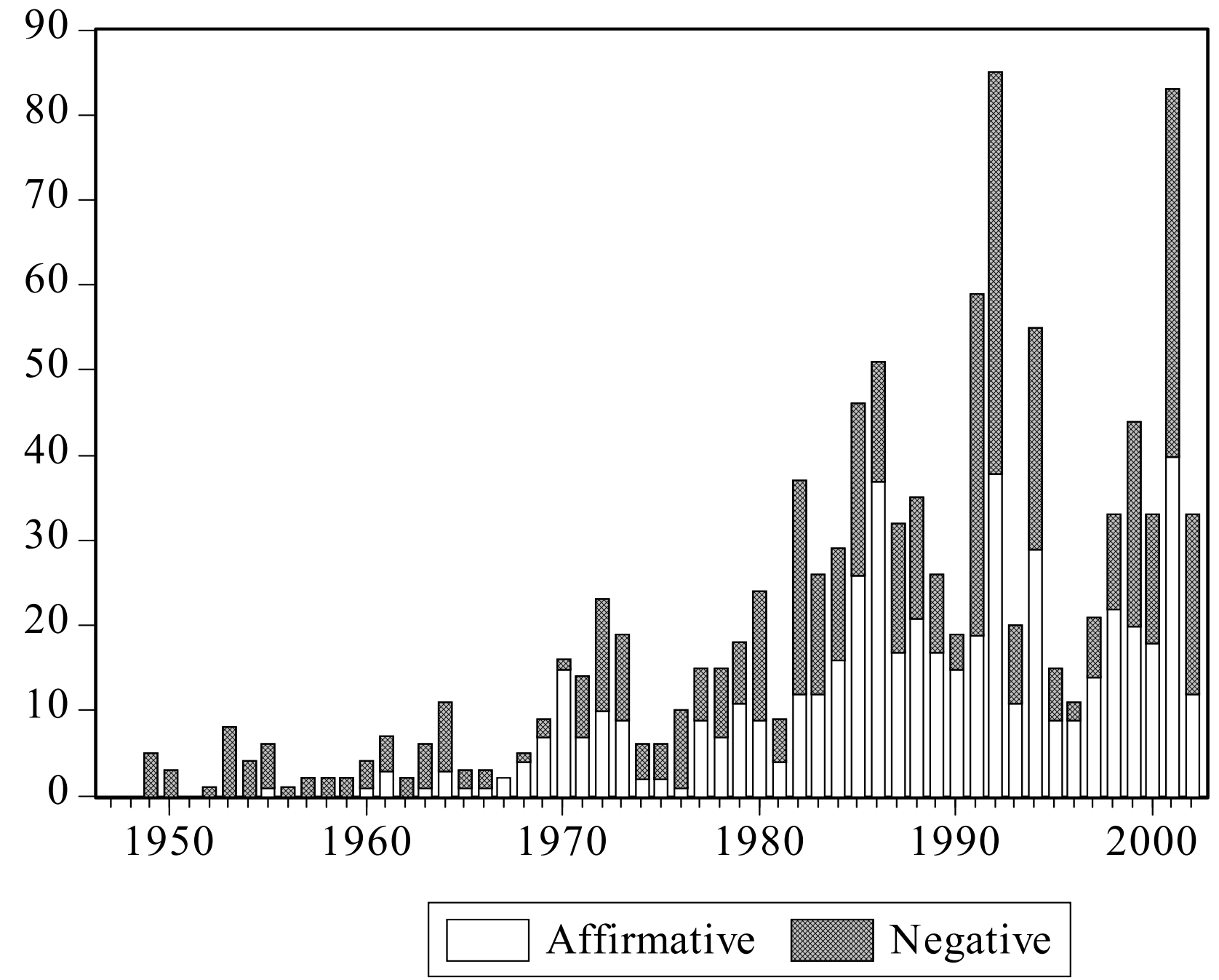

Source: See the appendix. 
Figure 5: Average Tariffs and Import Penetration, 1947 - 2002

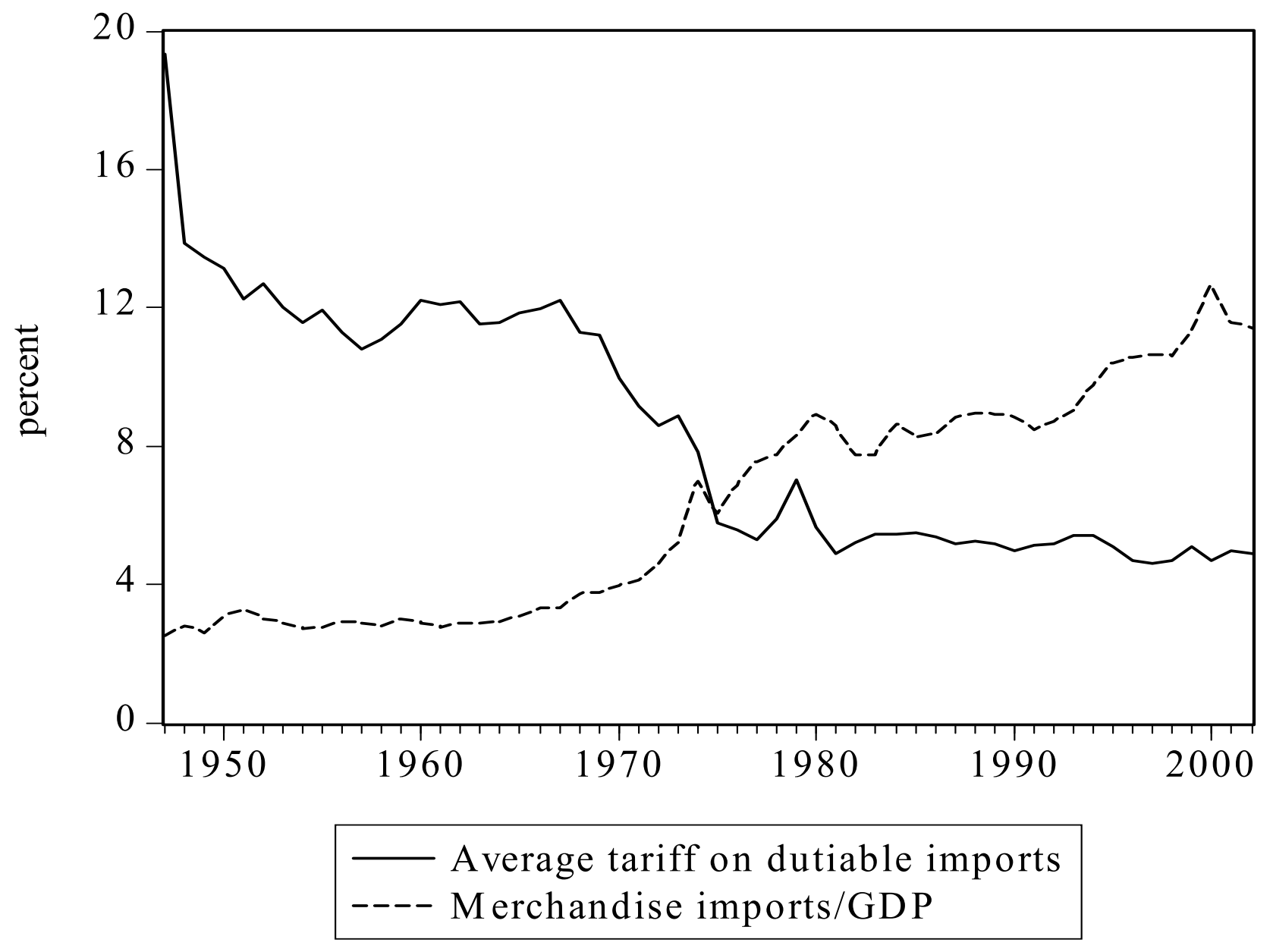

